\title{
DEBIUTY
}

Forum Pedagogiczne

$11(2021) 2$

DOI 10.21697/fp.2021.2.26

EWELINA LIGĘZA*

Warszawa, Polska

ORCID ID oooo-0oo2-5597-6436

\section{KARDYNAE STEFAN WYSZYŃSKI JAKO AUTORYTET W WYCHOWANIU MŁODZIEŻY - WYBRANE WSKAZANIA}

Streszczenie: Celem artykułu jest zwrócenie uwagi na to, w jaki sposób Stefan kardynał Wyszyński może stać się autorytetem dla współczesnej młodzieży. Aktualność nauczania Prymasa Tysiąclecia nadal może znaleźć odbiór i kształtować rozwój młodego człowieka, poprzez wspieranie jego wolności, odpowiedzialności oraz wiary. Dokonując życiowych wyborów, młodzież musi przestrzegać pewnych zasad, lecz dając sobie możliwość popełnienia błędu, gdyż to kształtuje jej tożsamość i sumienie. Każdy moment życia człowieka jest ważny, a w sposób szczególny ten, który wskazuje na wychowanie rodzinne, to wtedy bowiem kształtuje się szczególna więź między rodzicami a dziećmi. Dzięki prawidłowo stworzonej relacji w tym czasie nie będzie trzeba oddziaływać na młodych ludzi siłą, lecz wystarczy spokój i delikatność oraz dobroć serca.

Słowa kluczowe: młodzież, wolność, wiara, rodzina, wychowanie.

\section{Wprowadzenie}

Młodzież, u której najbardziej kształtuje się tożsamość, zawsze potrzebowała wzorować się na kimś, kto daje jej przykład postępowania w różnych sytuacjach i wyzwaniach, jakie stawia przed nimi życie. Kardynał Wyszyński w swoim nauczaniu poruszał znaczenie wychowania, a także pracy, a zatem wyborów, jakie stoją przed młodymi ludźmi. W dzisiejszym świecie istotne jest znalezienie odpowiedniego autorytetu, który wskaże na odpowiedzialność za siebie i drugiego człowieka, prawidłowo pojmowaną wolność oraz posługiwanie się zasadami etyki, a nade wszystko ukaże sens egzystencji człowieka, który w swoim życiu powinien zadbać o każdą sferę rozwoju.

* Ewelina Ligęza, Uniwersytet Kardynała Stefana Wyszyńskiego w Warszawie; e-mail: e.ligeza@ uksw.edu.pl. 
Szczególnie w okresie adolescencji pojawia się tak wiele dylematów, z którymi wiele jednostek nie jest w stanie sobie poradzić. Wybory życiowe niekiedy wydają się być zbyt poważne, a młody człowiek może sądzić, że nie jest w stanie ich dokonać w sposób prawidłowy.

Wreszcie należy spojrzeć na młodego człowieka jako na jednostkę, która chce zdobywać świat, mieć wszystko w zasięgu ręki, a napotyka na różne ograniczenia, które mogą powodować bunt wobec wszelkich idei. W takiej sytuacji wzorem do naśladowania może okazać się postać kardynała Wyszyńskiego, który, jako osoba, zwracał uwagę na zagadnienia odpowiedzialności, sprawiedliwości i miłości.

Dlaczego właśnie kardynał Stefan Wyszyński może być autorytetem dla młodego pokolenia? Prymas Polski swoje słowa w licznych kazaniach kierował właśnie do młodzieży: ,Ja nie jestem agitatorem, tylko nauczycielem i poniekąd wychowawcą" (Wyszyński 1999, s. 91). Pragnął on zatem szeroko pojmowanego dobra w wychowaniu i edukacji młodzieży, dobra indywidualnego, ale służącego społeczeństwu.

\section{Rodzina jako miejsce dojrzewania młodego człowieka}

Kościół zawsze opowiadał się za wartością rodziny oraz ochroną i szczególnym poszanowaniem każdego ludzkiego życia. Ze względów moralnych oraz etycznych nie popierał antykoncepcji. W latach 8o. postulowano, aby wspomagać rodziny, szczególnie wielodzietne, ze względu na koszty utrzymania, poprzez zasiłki rodzinne (Auleytner 2010).

Kardynał Wyszyński zaznaczał, iż „trzeba mocno trzymać się rodzinnej skały, aby nie spaść na dno przepaści” (Wyszyński 1998, s. 5). Mając na uwadze to przesłanie, to rodzina, jako podstawowa grupa społeczna, jest i zawsze będzie w stanie dać człowiekowi największe oparcie i siłę do powstania nawet z największego upadku. Rodzina jest zatem siłą narodu i jednostki.

Rodzina w nauczaniu księdza Wyszyńskiego jest wspólnotą, które przygotowuje młodego człowieka do przyszłości, obejmującej wychowanie moralne. Stąd tak istotny staje się tu proces socjalizacji oraz nawiązywania więzi pomiędzy członkami rodziny (Iwan 1985).

Charakterystyczny w dojrzewaniu jednostki jest okres adolescencji. Wtedy to młodzi ludzie więcej spotykają się ze sobą, a zdecydowanie mniej czasu poświęcają rodzinie. Niekiedy nawet wstydliwe jest dla nich pokazywanie się z rodzicem w środowisku rówieśniczym. Nade wszystko jednak kardynał zwracał uwagę na to, aby okazy wać młodym ludziom ciepłe rodzicielskie uczucia oraz przejawiać im swoją troskę. Nie powinno się wskazywać wyłącznie na błędy popełniane przez młodych ludzi, gdyż każdy ma do nich prawo. Ponadto ważne jest okazywanie zrozumienia, bycie towarzyszem, ponieważ młodzież „potrzebuje radości i chce wiedzieć, że jest Ktoś, kto ją kocha” (Wyszyński 1963, s. 24).

Różnica międzypokoleniowa oraz zamartwianie się rodziców o własne dzieci mogą być czynnikami drażniącymi dorastającą młodzież. Niekiedy osoby dorosłe, 
nie wiedząc już, jak dotrzeć do swoich dzieci, podnoszą głos, zbyt drastycznie narzucając młodzieży podporządkowanie się swoim przekonaniom, których ci mogą nie rozumieć. „Tam gdzie trudno dotrzeć podniesionym głosem, nawet dotkliwymi karami, można czasami znacznie łatwiej uzyskać oczekiwany efekt prośbą, podjęciem próby spokojnej rozmowy, nastawionej na znalezienie rozwiązania zaistniałej sytuacji, zaproponowaniem pomocy i poświęceniem czasu na zrozumienie problemów i motywacji będących przyczyną niepożądanych społecznie zachowań" (Grygier 2005, s. 46). Zatem poprzez propozycję pomocy, a nie narzuconą pomoc, łatwiej dotrzeć można do pokolenia, jakie w tak młodym wieku w sposób naturalny będzie przechodziło okres buntu wobec idei i wartości.

Ważną kwestią w tym wieku okazuje się być nauka, to młody człowiek bowiem staje przed nowymi wyborami w życiu. Na naukę składają się lata pracy, począwszy od przedszkola, szkoły podstawowej, aż po szkołę średnią. Taka droga niejako kształtuje pewien kierunek wyboru ścieżki zawodowej, przed jakim staje każdy młody człowiek. Również na tej płaszczyźnie młodzież będzie oczekiwała od rodziców odpowiedniego wsparcia. W momencie starania się o daną ocenę w szkole nie każda próba jej zdobycia kończy się wymarzonym sukcesem rodziców. Nawet tu młodzież zaznacza, że niektóre przedmioty są jej obojętne, a kardynał Wyszyński wskazywał na wartość ogólnego rozwijania się dla dobra jednostki i społeczeństwa. W tym wieku młodzi ludzie w sposób szczególny potrzebują docenienia, szczególnie jeśli mamy na uwadze zakończenie szkoły z ocenami pozwalającymi przejść na dalszy etap edukacji. Bardzo często wtedy właśnie rodzice stawiają młodzieży granice, jakie trudno jest jej przezwyciężyć. W sytuacji, kiedy rodzic okazuje niezadowolenie z jakiejś oceny, to wysiłek młodego człowieka nie jest doceniany. Nie chodzi tu, aby popierać niechęć do nauki, ale żeby odpowiednio rozmawiać, tłumaczyć, motywować, rozumieć próbę podejścia do nauki przez młodego człowieka. W momencie, kiedy to rodzic będzie tylko krytykował zdobyte przez dziecko oceny, nie powstanie odpowiednia relacja wychowawcza, pozwalająca na zaufanie i dająca poczucie bezpieczeństwa dziecku, że może ono przyjść do rodzica z każdym problemem (Sakowska 1999).

Kardynał Wyszyński, przypisując wyjątkową rolę rodzinie, tłumaczył, że jeśli jest ona zdrowa w znaczeniu moralnym oraz biologicznym, to wtedy przedłuża ona życie danego narodu, kształtuje jego tożsamość i wskazuje na jego rozwój. Taka komórka społeczna jak rodzina, ma swoje szczególne miejsce w społeczeństwie. To dzięki niej w narodzie można dostrzec jego przyszłość (Wyszyński 1981).

\section{Wychowanie do wolności}

Młodzi ludzie praktycznie w każdej sferze życia chcą decydować o sobie i samodzielnie podejmować decyzje. Niejednokrotnie, ukrywając niektóre fakty przed dorosłymi, nade wszystko rodzicami, a w dalszej kolejności wychowawcami, niekiedy zdarza się im popełniać błędy. Czasami wartość błądzenia jest tak znaczna, 
że w chwili, gdy dany problem odkryją dorośli, trudniej jest pozytywnie zakończyć niektóre sytuacje.

Prymas Wyszyński szczególne znaczenie nadawał wolności. Na pewno jedną z przyczyn były czasy, w których żył i nauczał. „Wielkim jest prawo do wolności! Złożył je w naturze człowieka sam Bóg. Jest ono tak wielkie, że poruszyło nawet niebo i głosem swoim doszło do łona Trójcy Świętej, «wstrząsając» niejako wewnętrznym szczęściem samego Boga. Oto Ojciec Niebieski nie przyjął ofiar Starego Zakonu, składanych mu ze zwierząt na Syjonie, ale Synowi swojemu ciało sposobił, ażeby Bóg-Człowiek złożył je w obronie wolności swych braci. Przez krzyż, ofiarę z Ciała i Krwi swojej, Chrystus wyzwolił człowieka. Aż tak potężne jest prawo do wolności" (Wyszyński 1994, s. 9). Zatem skoro wolność jest darem Boga dla każdego człowieka, to dar ten należy rozwijać, nie można go marnować albo użytkować w zły sposób, Bóg bowiem nie dał człowiekowi tego daru po to, aby ten czynił nim zło. W imię tego, wolność to przestrzeganie zasad, z którymi dziś nie do końca zgadza się młodzież, chcąc być bardziej nowoczesna i szybciej zdobywać narzędzia do wkraczania w dorosłość, takie jak łatwość zarobienia pieniędzy czy zakupu wymarzonego gadżetu. Także sam Chrystus przyjął śmierć krzyżową dla wolności człowieka. Podjął się zatem cierpienia, chociaż jako BógCzłowiek być może mógłby przejść inną, lżejszą drogę. Owa droga ukazuje też kroczenie młodego człowieka po ścieżkach życia. Szukając, wybierając nieprawidłowe kierunki, młodzież często cofa się lub stoi w miejscu, podczas gdy przyjęcie wszystkich zasad, jakie panują w świecie, a zatem norm prawnych, społecznych, porządkowych i innych obowiązujących mogłoby ją najbardziej naprowadzić na dojście do ostatecznego celu. Któż jednak dziś z dorosłych potrafi przyznać się do młodzieńczych błędów? Raczej obecnie taki człowiek wskazałby, iż owo działanie w młodości było konieczne i nieuniknione. $\mathrm{Z}$ racji na to trzeba nam wczuć się w postępowanie i decyzje młodzieży, której stale trzeba towarzyszyć, ale i rozumieć, że mają oni prawo do wolności, gdyż każdy człowiek ma swoją godność.

Podejmując temat wolności, należy jeszcze odwołać się do kwestii sumienia, które przecież posiada każdy człowiek. W wieku adolescencji sumienie dojrzewa wraz z człowiekiem, kształtuje się, odczuwając to, co jest dobre, a co pozostawia na nim pewną ranę czy nawet boleść. Istotne jest zatem odpowiednie towarzyszenie młodzieży, ponieważ ,ludzie nie mogą mieć za sobą «naganiaczy» zamiast własnego sumienia" (Wyszyński 1990, s. 990). Należy więc zrozumieć błędy młodzieży i pomóc je naprawiać, gdyż jest to swego rodzaju pewna lekcja życia. Ukazuje to również sens człowieczeństwa, wiążący się z nieustannym poszukiwaniem, a w tym przypadku, poznawaniem i odkrywaniem siebie. Inne znaczenie nadałaby młodzieży opowieści będącej przykładem z życia dorosłych, a inne własnym doświadczeniom. Ważne jest więc posługiwanie się rozumem i jego kształtowanie. Gdyby młody człowiek był tylko naganiany do pewnych zachowań czy zaspokajania ambicji rodziców, funkcjonowałby jak maszyna, bez przemyśleń, podczas gdy życie jest procesem, z którego wynikają pewne sytuacje, z jakimi należy się zmierzyć. 
Wolność nie oznacza samowoli, co też w swoim nauczaniu zaznaczał Prymas Tysiąclecia. Uważał on, że im bardziej ukształtowane jest sumienie człowieka, a więc odczuwanie tego, co jest dobre i prawe oraz tego, co jest złe i niszczące, tym osoba bardziej oddala się od owej samowoli, dostosowując się zarazem do zasad moralnych (Wyszyński 1981). Zatem jeżeli rodzina ubogaci młodego człowieka wieloma doświadczeniami, uwrażliwiając go na potrzeby innych czy nierówności społeczne, być może taka jednostka będzie w stanie w przyszłości lepiej zrozumieć drugiego człowieka i wykazywać się względem niego altruizmem. Co więcej - sumienie pozwala na spotkanie się podmiotu z Nieskończonością i przekraczanie samego siebie. Tę myśl zaznaczał Wyszyński w narodowym programie edukacji moralnej. Pokładał on zatem ufność w człowieku i wierzył, że nawet gdy popełnia on błędy, może się nawrócić. Jakże znaczącą rolę przypisywał jednostce i samemu człowieczeństwu... (Wyszyński 1971).

\section{Ożywianie wiary młodzieży przykładem Prymasa Tysiąclecia}

Kardynał Stefan Wyszyński był człowiekiem wiary. Niejednokrotnie w swoich kazaniach do młodych ukazywał wartość Boga i dawał świadectwo wiary, aby móc pociągnąć za sobą innych ludzi w dobrym kierunku. Budowanie żywego Kościoła było istotą jego działania: „W sposób szczególny buduje go swoim żywym słowem: słowem apostolskiego przepowiadania, słowem bogatym i szczodrym, słowem prawdy, nadziei i miłości. To prymasowskie słowo stało się (...) głosem sumienia, w którym wypowiada się godność człowieka i jego wolność" (Wyszyński 1998, s. 5).

$\mathrm{Na}$ takie właśnie przesłanie wskazuje myśl, że jeśli będziemy sprawiedliwie odnosić się do Boga, to podobnie będziemy zwracać się do drugiego człowieka (Wyszyński 1963). Prymas zatem zaznaczał rolę cnoty sprawiedliwości, jak również szczególne traktowanie innego bytu. Szacunek do Boga przekłada się na szacunek do drugiego człowieka. Właściwie rzec można, iż relacja ta powinna być naturalna dla każdego człowieka, w szczególności będącego w wieku adolescencji. Wówczas często młodzież okazuje bunt względem innych i wobec Boga, odrzucając wiarę w Niego.

$\mathrm{Z}$ tego względu Prymas zwracał uwagę na znaczenie miłości w wierze. Ona bowiem zaspokaja potrzeby młodego człowieka i poniekąd też odpowiada za jego uspołecznienie. Należy zatem zwracać się ku miłości, gdyż to ona uwrażliwia młodego człowieka, a w przyszłości owocuje egzystencją (Wyszyński 1973).

Kardynał zaznaczał, że w wychowaniu młodego pokolenia dostrzegany jest problem teologiczno-pastoralny. Jak zatem ożywić wiarę młodych, kto miałby być dla młodych autorytetem, dając wskazówki na etapie dojrzewania, ukierunkowując na wiarę? (Rynio 1995).

$\mathrm{Na}$ lekcjach religii w szkole autentyczność nauczyciela religii ma ogromne znaczenie w pojmowaniu wiary przez młodzież. Dobry przykład może zaowocować dobrym podejściem do kwestii wiary, a nawet nawiązaniem głębokiej relacji 
z Bogiem. Zatem „,młodzież łatwiej uwierzy tym doradcom, którzy widzą możliwość korzystnej zmiany i dostrzegają walory w każdym, nawet pełnym wad, w jakiejś mierze zdefektowanym człowieku" (Szymański 2004, s. 3). Kwestia ta wskazuje, że młodzież musi mieć pewien obszar dozwolonego błądzenia, aby mieć możliwość czuć się jak jednostka, która potrzebuje pomocy. Poniekąd ten właśnie wiek jest pewną manifestacją odejmowaną przez młodego człowieka, walczącego o to, aby jego problemy zauważyć.

Jeśli chodzi o znaczenie lekcji religii, Prymas twierdził, że nie jest to tylko zwyczajny przedmiot $\mathrm{w}$ szkole, ale egzamin $\mathrm{z}$ tych lekcji człowiek będzie zdawał przez całe swoje życie. Zachęcał także do zgłębiania religii w domach i do samodzielnego czytania lektur religijnych (Wyszyński 1975). Dzięki zgłębianiu prawd wiary w młodym człowieku będzie mieszkał Duch Święty. Młody człowiek będzie przeświadczony również o tym, iż osobiście spotyka się w swoim życiu z Chrystusem (Wyszyński 1975).

Kardynał Wyszyński rozumiał, że słowa do młodzieży należy kierować w takim języku, aby odpowiednio do nich dotrzeć. Przypisywał on również ogromne znaczenie pielęgnowaniu sakramentów świętych przez młodzież i kierował do młodych następujące słowa: ,starajcie się dochować wierności Ojcu Niebieskiemu, przepoić swoje życie wiarą, która pokona wszystkie trudności i przeciwności. Pogłębiajcie ją na katechizacji i żyjcie pełnią chrześcijaństwa na co dzień" (Wyszyński 1975, s. 565). Owo ożywianie wiary ma wypełniać się zatem nie tylko w Kościele, ale i w szkole, czyli tam, wychowuje się młode pokolenie. To wskazówka do tego, aby młody człowiek rozwijał każdą sferę swojego życia, a wtedy będzie doznawał w życiu ładu i harmonii. Istotną rolę Prymas przypisywał samej katechizacji, która wskazuje na godność człowieka i która rozwija człowieczeństwo w młodych ludziach.

\section{Rola jednostki w społeczeństwie w myśli księdza Wyszyńskiego}

Jakże człowiek zależny jest od współżycia społecznego... Bez poczucia obecności i bliskości drugiej osoby nie będzie rozwijał się prawidłowo. W okresie młodości rodzice stoją na nieco dalszym miejscu niż rówieśnicy, którzy mają podobne zainteresowania czy hierarchię wartości. W takim wieku młody człowiek ma poczucie wręcz niezrozumienia przez rodzinę, która narzuca mu jakieś zasady i stawia pewne cele do osiągnięcia, podczas kiedy to jednostka poszukuje swojej tożsamości.

Także w znaczeniu religijnym ksiądz Wyszyński wskazywał na rolę, jaką w wychowaniu człowieka odgrywa grupa społeczna. Twierdził on, że „człowiek ma skierowanie społeczne, dlatego może żyć i rozwijać swoje właściwości tylko dzięki stosunkom z innymi ludźmi” (Wyszyński 1968, s. 135). Wtedy człowiek ma swoje dążenia społeczne, a szczególnie młody człowiek, domaga się więc akceptacji w grupach, w których uczestniczy. Grupy te ubogacają bowiem jego codzienność. 


\section{Wychowanie dla narodu}

Kardynał Stefan Wyszyński w swoich wypowiedziach skierowanych do młodych ludzi niejednokrotnie podkreślał istotę wartości narodowych. Właśnie wychowanie dla narodu, dla Polski, stanowiło sens jego wielu kazań.

W wychowaniu dla narodu ogromne znaczenie odgrywała religijność. Uważał on, że wartością utylitarną jest praca i pozyskiwane do jej wykonywania narzędzia, ale ponadto młodzi ludzie powinni wkroczyć na odpowiednią kulturę ducha, co zapewni im stabilność (Wyszyński 1979). Nie pomijał zatem znaczenia narzędzi, dzięki którym człowiek może się rozwijać, ale zwracał uwagę na to, że sensem i źródłem, do którego powinni lgnąć młodzi, jest Bóg.

Młodzież, w całym narodzie, stanowiła dla kardynała grupę priorytetową, szczególnie ze względu na jej prawo do wychowania. $Z$ tego powodu, jak uważał, na każdą jednostkę należy patrzeć indywidualnie i społecznie, także cieleśnie i duchowo. Młody człowiek powinien mieć osobisty wybór własnej przyszłości, w której zawarte są konkretne cele, oraz wybór środków potrzebnych do własnego rozwoju. Prymas nakreślał więc znaczenie powołania każdego człowieka, które niesie za sobą konkretne działanie i szansę (Rynio 1995).

\section{Podsumowanie}

Postać tak wielkiego Polaka jak kardynał Stefan Wyszyński jest wzorem do naśladowania nie tylko dla ludzi dorosłych, lecz nade wszystko dla pokolenia ludzi młodych. To ono uczestniczy jeszcze w procesie nauczania, a więc katechizacji szkolnej, gdzie osoba tak znacząca dla historii Polski może odegrać wielką rolę w wychowaniu.

Zwrócenie uwagi na godność człowieka w nauczaniu m.in. religijnym, ale i narodowym, a zatem przyjęcie odpowiedzialności za swoją rodzinę oraz samorozwój zaowocuje w życiu młodzieży nabyciem dobrych cech, aby w przyszłości każdy wybierał właściwie oraz miał prawidłowe podejście do drugiego człowieka.

Kazania kardynała, w których tak bardzo zwracał uwagę na proces i znaczenie kształcenia oraz wychowania, świadczą o tym, że młodzież bardzo się dla niego liczyła. To do niej kierował swoje przesłanie, że należy opierać się na Bogu, gdyż wiedział, że młody człowiek szuka głębszego sensu w swoim życiu.

Mówienie o wartości społeczeństwa świadczyło o przekonaniu, że to jednostka tworzy dany naród, zatem na jaką przyszłość przygotujemy dzieci i młodzież, taki będziemy mieli kraj i tak będzie wyglądała nasza tożsamość narodowa.

Wreszcie istotną rolę w przesłaniach kardynała odgrywała wolność. Na pewno w czasach życia Prymasa Polski wartość ta znacznie się liczyła, a dziś sama młodzież pragnie owej wolności, przyzwolenia na wczesne podejmowanie decyzji o tym, $\mathrm{z}$ kim będzie się przyjaźniła oraz jaki kierunek naukowy obierze w życiu. Zatem rodzina ma ogromny wkład w socjalizację jednostki, ale na pewnym etapie to młody 
człowiek sam chce decydować o sobie. Kardynał Wyszyński zaznaczał, aby prawidłowo pojmować wolność, a więc łączyć ją z odpowiedzialnością za własne decyzje.

Ksiądz Wyszyński, jako tak wielka postać, ale i zarazem zwyczajny człowiek, nauczyciel, to osoba, która posiadała w sobie liczne cechy, aby stać się autorytetem także dla młodzieży. Wartości, jakimi kierował się w życiu, są ponadczasowe, a możliwość dotarcia do drugiego człowieka była znacząca.

\section{Bibliografia}

Auleytner J. (2010). Polska jako welfare state a rodzina - Stefan Wyszyński prekursorem katolickiej polityki społecznej. W: Marszałek L., Solak A. (red.). O społeczeństwie, wychowaniu i pracy w myśl Kardynała Stefana Wyszyńskiego. Warszawa: LABOR WNP

UKSW w Warszawie, s. 43-44.

Grygier U., (2005). Teraz wychowujemy. „Nowa Szkoła”, nr 3.

Iwan R. (1985). Nadzieja w postawie narodu. „Przegląd Powszechny”, nr 11, s. 230.

Rynio A. (1995). Wychowanie młodzieży w nauczaniu Kardynała Stefana Wyszyńskiego.

Lublin: Wydawnictwo KUL, s. 11.

Sakowska J. (1999). Szkoła dla rodziców i wychowawców. Warszawa: Centrum Metodyczne

Pomocy Psychologiczno-Pedagogicznej, s. 89-90.

Szymański M. (2004). Pochwała optymizmu. „Nowa Szkoła”, nr 7, s. 3.

Wyszyński S. (1998). Idącym w przyszłość. Warszawa: Wydawnictwo im. Stefana Kardynała Wyszyńskiego „Soli Deo”.

Wyszyński S. (1973). Idzie nowych ludzi plemię. Poznań-Warszawa: Wydawnictwo Pallottinum, s. 233-234.

Wyszyński S. (1999). Jedna jest Polska. Warszawa: Wydawnictwo im. Stefana Kardynała Wyszyńskiego „Soli Deo”.

Wyszyński S. (1994). Kamienie wołać będą. Warszawa: Instytut Prymasowski.

Wyszyński S. (1963). Kazania i przemówienia autoryzowane. Warszawa: Wydawnictwo im. Stefana Kardynała Wyszyńskiego „Soli Deo”.

Wyszyński S. (1981). Kościół w służbie narodu. Rzym: Wydawnictwo Pallottinum, s. 9. Wyszyński (1975). Listy Pasterskie Prymasa Polski. Paryż: Société d’Éditions Internacionales, S. 181,605 .

Wyszyński S. (1971). Miłość na co dzień. Rzym: Papieski Instytut Studiów Kościelnych, s. 157. Wyszyński S. (1990). Nauczanie społeczne 1946-1981. Warszawa: Optimus.

Wyszyński S. (1981). Sumienie prawe. U podstaw odnowy życia narodowego. PoznańWarszawa: Wydawnictwo im. Stefana Kardynała Wyszyńskiego „Soli Deo”, s. 5-6.

Wyszyński S. (1968). Bejze B. (red.). U podstaw soborowej nauki o człowieku. W nurcie zagadnień posoborowych. Warszawa: Wydawnictwo Sióstr Loretanek.

Wyszyński S. (1963). Uświęcenie pracy zawodowej. Paryż: Société d'Éditions Internationales s. 262.

Wyszyński S. (1979). Z rozważań nad kultura ojczystą. Poznań: Instytut Wydawniczy PAX, s. 97-98. 


\title{
CARDINAL STEFAN WYSZYŃSKI AS AN AUTHORITY FOR CONTEMPORARY YOUTH - SELECTED INDICATIONS
}

\begin{abstract}
The aim of the article is to draw attention to how Stefan Cardinal Wyszyński can become an authority for contemporary youth. The topicality of the teaching of the Primate of the Millennium can still be received and shaped the development of a young person by supporting his freedom, responsibility and faith. When making life choices, young people must follow certain rules, but give themselves the opportunity to make a mistake, as this shapes their identity and conscience. Every moment of a person's life is important, and in a special way the one that indicates family upbringing, because it is then that a special bond is formed between parents and children. Thanks to a properly created relationship at this stage, you will not have to exert force on young people, but with peace, gentleness and kindness of the heart.
\end{abstract}

Keywords: youth, freedom, faith, family, education. 
